\title{
Lithology-Controlled Hydrodynamic Behaviour of a Fractured Sandstone-Claystone Body in a Radioactive Waste Repository Site, SW Hungary
}

\author{
Emese Tóth *(D), Ervin Hrabovszki, Félix Schubert and Tivadar M. Tóth $\mathbb{D}$ \\ Department of Mineralogy, Geochemistry and Petrology, University of Szeged, Egyetem Str. 2, \\ 6722 Szeged, Hungary; ervin.hrabovszki@geo.u-szeged.hu (E.H.); schubert@geo.u-szeged.hu (F.S.); \\ mtoth@geo.u-szeged.hu (T.M.T.) \\ * Correspondence: tothemese@geo.u-szeged.hu
}

check for

updates

Citation: Tóth, E.; Hrabovszki, E.;

Schubert, F.; M. Tóth, T.

Lithology-Controlled Hydrodynamic

Behaviour of a Fractured

Sandstone-Claystone Body in a

Radioactive Waste Repository Site,

SW Hungary. Appl. Sci. 2022, 12, 2528.

https://doi.org/10.3390/

app12052528

Academic Editor: Kelin $\mathrm{Hu}$

Received: 7 February 2022

Accepted: 25 February 2022

Published: 28 February 2022

Publisher's Note: MDPI stays neutral with regard to jurisdictional claims in published maps and institutional affiliations.

Copyright: (C) 2022 by the authors. Licensee MDPI, Basel, Switzerland. This article is an open access article distributed under the terms and conditions of the Creative Commons Attribution (CC BY) license (https:// creativecommons.org/licenses/by/ $4.0 /)$.

\begin{abstract}
The fracture network modelling and hydrogeological assessment were performed in an $845 \mathrm{~m}$ deep borehole of the potential high-level waste repository formation and its caprock. The geometry of the fracture network was simulated using the discrete fracture network (DFN) modelling method, which is based on the geometric characteristics of the individual fractures. The hydrogeological evaluation was based on changes in porosity and permeability along the borehole using flow zone indicator (FZI) values that denote hydraulic flow units (HFU) within the rock body. Fracture network characteristics and hydrogeological features are mainly determined by the wellbore lithology, which can be divided into three zones. The sandstone body was intersected in the upper $300 \mathrm{~m}$ of the borehole, which forms a single HFU. The second zone was developed along with the transition zone between the sandstone and the underlying claystone bodies. Here the predominant rock type is claystone, but the characteristics of the fracture network are distinctly different from the deeper parts of this rock body. Below $400 \mathrm{~m}$ is the third zone, where distinct and extensive HFU-s could not form, probably due to different water-rock interaction processes that could have changed the porosity and permeability from point to point in the claystone.
\end{abstract}

Keywords: DFN modelling; fracture network; fracture aperture; flow zone indicator; high-level radioactive waste repository; Boda Claystone Formation; Kővágószőlős Sandstone Formation

\section{Introduction}

Several studies dealt with the potential host rock for a repository for high-level radioactive waste in Hungary [1]. This is the Boda Claystone Formation (BCF); a formation with very low porosity and low permeability, that provides good retention properties for the repository. In addition to the intrinsic properties of the argillaceous rock, the host formation and the overlying and underlying formations must have specific favourable properties to be considered a possible site for a nuclear waste repository [2,3]. Exploration and investigation of the adjacent rock formations are critical, especially the investigation of the fracture networks that may developed across the formations. This is because the fluid flow in a claystone body could be related to its fracture system $[4,5]$.

The caprock of the BCF is the Kővágószőlős Sandstone Formation (KSF), which has markedly different rheological and hydrogeological properties than the underlying impermeable claystone. Despite the uniform structural evolution, the different rheological properties of the formations could significantly influence fracturing and the resulting fracture system. Many aspects of fracturing are influenced considerably by the rheological properties of the host rock. Different rock types respond differently to the same stress field $[6,7]$.

The deep well BAF-3 aimed to explore the caprock of the BCF and reached a depth of more than $800 \mathrm{~m}$ with a core recovery of almost 100\%. The well intersected the KSF and 
drilled more than $400 \mathrm{~m}$ of the 700-900 $\mathrm{m}$ thick BCF. The boundary between the sandstone and the claystone formations is $343.08 \mathrm{~m}$ (reported depths are in total measured depth in metres throughout the paper). This borehole allows the differences in the properties of the fracture systems of different host rocks to be investigated and compared. This work aims to model the fracture network geometry of two different rock types in one borehole, investigate the differences in their natural fracture system, and evaluate the borehole hydrogeologically.

\section{Geological Setting}

The Kővágószőlős Sandstone Formation and the Boda Claystone Formation are part of the 4000-5000 m thick Palaeozoic-Triassic sedimentary sequence of the Western Mecsek Mountains in SW Hungary (Figure 1) [8].

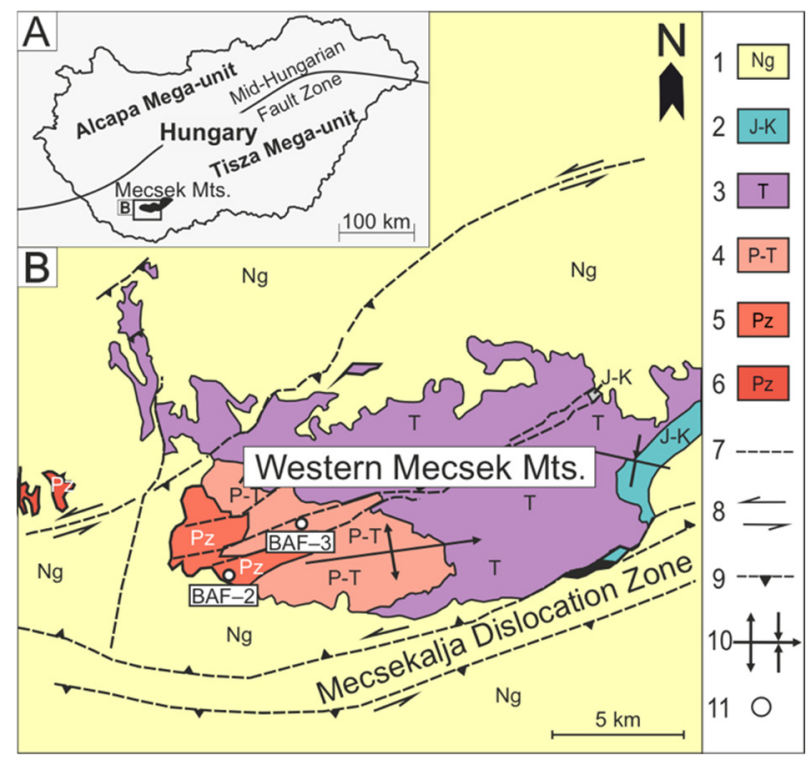

Figure 1. (A) Map of Hungary with the location of the Mecsek Mountains. (B) Geological map of the Mecsek Mountains with the distribution of the Kővágószőlős Sandstone Formation and the Boda Claystone Formation; modified after [9]. Legend: 1-Neogene sediments; 2-Jurassic and Cretaceous sediments and Cretaceous volcanic rocks; 3 - Triassic sediments (sandstones, carbonates and evaporites); 4-Upper Permian-Triassic Kővágószőlős Sandstone Fm; 5-Upper Permian Boda Claystone Fm; 6-Palaeozoic; 7-fault; 8-strike-slip fault; 9-thrust fault; 10-syncline and anticline; 11-well site.

The KSF was deposited in continental (fluvial and paludinal) facies in a hot, semiarid climate $[10,11]$. Due to the uneven subsidence of the depositional environment, the fluvial basin, the known thickness of the formation varies between 150 and $1400 \mathrm{~m}$ [12]. Based on sporomorphs the uppermost part of the KSF can be dated to the Triassic. The Permian-Triassic boundary can be drawn within the formation [13].

The KSF consists of a rhythmic succession of coarse- and fine-grained beds. The major sedimentary cycle begins with conglomerates, and the middle part consists of relatively fine-grained sandstone layers. The upper part of the formation becomes coarser again, and the uppermost part ends with coarse sandstone with pebbles, which could be related to regression [14]. Based on the predominant colour of the sandstone layers, the formation could be divided into three heterotopic members: the deepest member is the varied sandstone (Bakonya varied sandstone), followed by the grey sandstone (Kővágótöttös Sandstone) and the red sandstone (Cserkút Red Sandstone) at the top [11,14]. At the boundary between the grey and red sandstones, a layer of green sandstone could be separated (Kajdács völgy Sandstone), with which significant uranium ore enrichment is associated [11]. 
The underlying formation of the KSF is the Boda Claystone Formation, a reddishbrown formation composed of claystone, siltstone, albitolite with dolomite and fine sandstone interbeds $[15,16]$. Due to its extent $\left(150 \mathrm{~km}^{2}\right)$, thickness $(700-900 \mathrm{~m})$ and impermeable properties, it is suitable for the proposed repository for high-level radioactive waste [1]. BCF was deposited in a lacustrine environment, in an alkaline lake on a periodically drying playa mudflat in an arid to semi-arid climate [15,17-20].

The study area is within the subvertical profile of well BAF-3, which intersected both formations in a considerable thickness. The borehole is $845 \mathrm{~m}$ deep, quaternary sediments are located in the uppermost $2.76 \mathrm{~m}$, the Kővágótöttös member (grey sandstone) of the KSF is found between 2.76 and $112.46 \mathrm{~m}$, and the Bakonya member (variegated sandstone) of the KSF is located below it, between 112.46 and $343.08 \mathrm{~m}$. The boundary of the two formations is at $343.08 \mathrm{~m}$, below that BCF is located. Between 691.2 and 695.6 , there is a reductive layer in the $\mathrm{BCF}$, which has been documented in several other boreholes as well (Figure 2) [21].

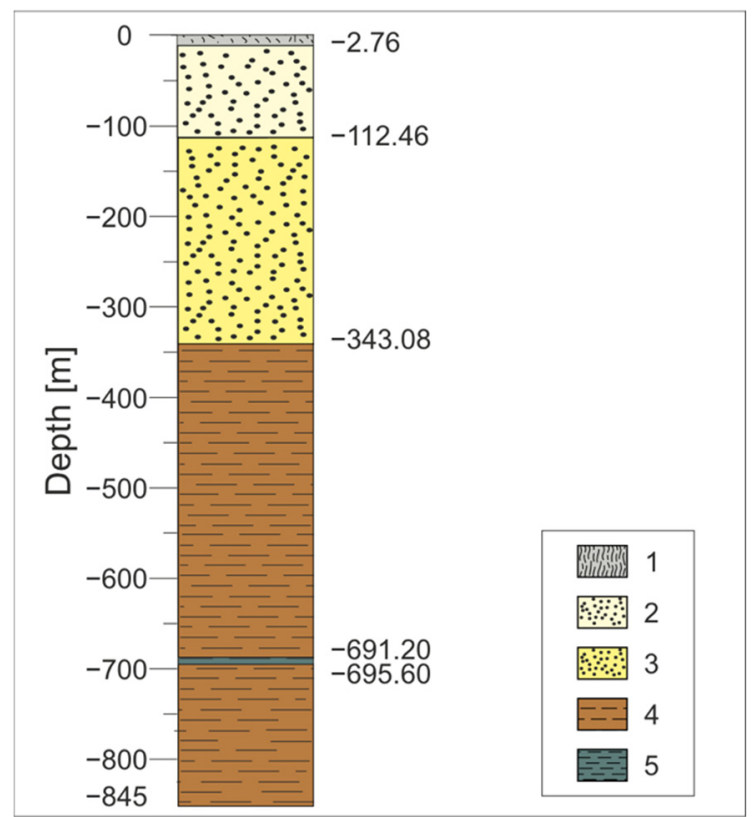

Figure 2. Lithology log of the BAF-3 well; 1-quaternary sediments; 2-grey sandstone; 3variegated sandstone; 4 -claystone with siltstone beds; 5 -greenish-black reductive claystone.

Numerous successive tectonic phases characterise the tectonic evolution of the area. In the Late Cretaceous, a significant NE-SW shortening is documented [22]. The main tectonic events in the Neogene are related to the formation of the Pannonian Basin. In the early Miocene, tensional stresses [23-25] and in the late Miocene, compression [26] led to deformation in this area. This event was followed by thermal subsidence of the basin during the Pannonian $[27,28]$. The most recent significant event is the ongoing tectonic inversion of the basin [9].

The dip direction of the bedding of the sandstone in the borehole is NE, while the dip direction of the claystone is predominantly E. Based on the analysis of the BHTV (borehole televiewer) data, the distribution of fractures is similar in the two formations, suggesting that the fracture system is the result of the younger tectonic events that affected both formations [21].

Previous studies have distinguished four vein generations in the $\mathrm{BCF}$, indicating four different tectonic and/or vein cementation processes. The four categories are the branched veins, the straight veins, the en-echelon vein arrays and the breccia-like veins [29-32]. The fractures are filled dominantly with calcite, anhydrite, and barite-celestine [15,29-32]. 
Accurate knowledge of hydrogeological conditions is an essential prerequisite for evaluating the suitability of a geological formation for radioactive waste disposal. The position of the Western Mecsek Mountains determines the general hydrological conditions of the studied area. The Palaeozoic-Mesozoic formations rise 400-500 m from their surroundings and define a regional recharge zone whose drainage basins are the Neogene basins in their wider surroundings [33]. Based on the BAF-3 hydraulic tests, the transmissivity in the two formations differs significantly (Figure 3 ).

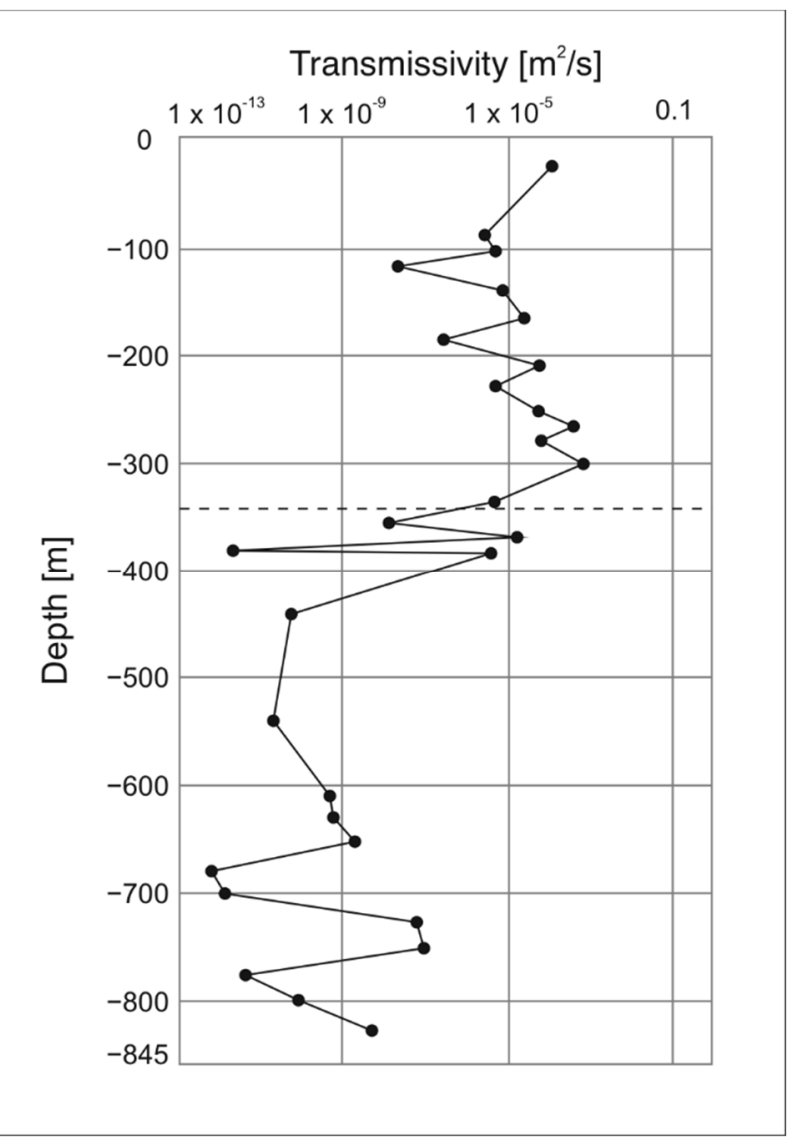

Figure 3. Transmissivity log of the BAF-3 well based on well-hydraulic testing, dashed line denote the KSF-BCF border [34].

KSF has higher transmissivity values without large deflections $\left(2.7 \times 10^{-8}-7.11 \times\right.$ $10^{-4} \mathrm{~m}^{2} / \mathrm{s}$ ). Transmissivity values drop significantly at the boundary of the two formations; BCF has lower transmissivity values between $6.79 \times 10^{-13}$ and $1 \times 10^{-7} \mathrm{~m}^{2} / \mathrm{s}$ [34].

\section{Methods}

Fracture networks in rocks are fractal-like objects that can be modelled at any scale based on the geometric parameters of the individual fractures that make up the fracture network $[35,36]$. This study used discrete fracture network (DFN) modelling to investigate the differences between fracture networks of different host rocks [37]. Primary data for modelling are the geometric parameters of individual fractures, i.e., fracture length distribution, spatial density, the orientation of fractures and their aperture. Based on these geometric parameters, a discrete fracture network was created using the Infress software [38-40].

Fracture length is an essential geometric parameter of DFN modelling. Numerous studies have shown that the distribution of fracture lengths follows a power-law function so that

$$
\mathrm{N}(\mathrm{L})=\mathrm{F} \times \mathrm{L}^{-\mathrm{E}}
$$


where $\mathrm{N}(\mathrm{L})$ is the number of fractures of length $\mathrm{L}$, and $\mathrm{E}$ and $\mathrm{F}$ are the parameters of the distribution function [41,42]. This asymmetric distribution means that the number of small fractures is significantly larger than the number of large fractures. Measurements of fracture lengths were performed according to the M. Tóth [39] method, which requires two images, using two methods with different sensitivities. The number of fractures detected with the less sensitive way is necessarily less than the number of fractures seen with the more sensitive method, with a constant difference $(\Delta \mathrm{N}(\mathrm{L}))$. Based on this difference and the detection limits of the methods used, the parameters of Equation (1) can be calculated. For further details, see [39]. The length exponent was determined using core images (higher resolution, $1 \mathrm{~mm}$ ) and BHTV data (lower resolution, $3 \mathrm{~mm}$ ).

The fractal dimension defines the spatial density of the fracture network. In a borehole, the fracture network is intersected by a line, resulting in a series of points. In this case, the spatial density of the fractures can be characterised by calculating the fractal dimension of the point series. Fractal dimension was calculated at every $50 \mathrm{~m}$ interval with an overlap of $25 \mathrm{~m}$ along the well, using Benoit 1.0 software [39]. The parameter P10 was also used to determine the fracture density, which is the number of intersections per metre. This parameter was also calculated for every $50 \mathrm{~m}$. The orientations of the fractures were characterised by the dip direction and the dip angle obtained from the BHTV data.

Infress fracture network modelling software simulates individual penny-shaped fractures in a stochastic manner using the given geometric parameters of the fracture network. It generates the desired number of equally probable realisations of the geometry of the fracture network and allows defining of the size and spatial position of the communicating subsystems of the simulated fracture networks $[39,43,44]$.

The fracture aperture is an essential parameter for evaluating the hydraulic conductivity behaviour of a fractured rock body. There are several ways to determine the aperture of a fracture. The physical aperture is defined as the average distance between the opposing walls of the fracture, which can be physically measured at any scale. The aperture of a natural fracture is influenced by the prevailing stress field, the orientation of the fracture, the depth and the roughness of the fracture wall. The aperture can be altered by water-rock interaction processes, which may affect the original aperture differently from part-to-part along the fracture plane. For understanding hydrodynamic processes, on the other hand, the hydraulic aperture should be used, which is defined as the width of a theoretical pipe that produces the same flow rate as the actual fracture does $[45,46]$.

Using the Infress software, the fractured porosity and intrinsic permeability tensor elements can be calculated for each cubic volume element of the modelled rock body, if the aperture of the fractures is known [40]. Previous studies show that fracture aperture is in a significant linear correlation with the fracture length $[35,47,48]$ :

$$
\mathrm{a}=\mathrm{A} \times \mathrm{L}
$$

where $\mathrm{a}$ is the aperture, while the aperture coefficient A is characteristic for the rock body and the fracture system and $\mathrm{L}$ is the length of the fracture. The initial aperture can be calculated for each fracture with the modelled length using this correlation. Finally, the modelled fractured porosity and permeability values estimated for each cubic cell depend solely on the geometry of the fracture network and the aperture coefficient (A).

The hydraulic aperture of the fractures in well BAF- 3 can be estimated by comparing the observed and modelled permeabilities. First, porosity and the $3 \times 3$ intrinsic permeability tensor for an arbitrary cubic cell should be computed based on the generated geometry of the fracture network using an aperture coefficient value. Since the hydraulic measurements of the well do not consider the anisotropy of the permeabilities, the average of the diagonal elements of the permeability tensor is used in the subsequent calibration. 
The observed permeability can be calculated from the measured transmissivity at any depth interval. The aperture coefficient of the modelled fracture system can be calibrated using the observed and the modelled permeability values. The goal of aperture calibration is to change the value of the aperture coefficient so that the two permeability values become equal. To estimate the permeability tensor with the Infress code, a rock volume of $\mathrm{d}^{3}$ was considered, where $d$ is the length of the interval used for well-hydraulic measurements, usually $20 \mathrm{~m}$. In this way, an average aperture coefficient could be calculated for each interval independently so that the effective porosity can also be calculated for all sections afterwards.

The hydrodynamic properties of a rock body can be described by the flow zone indicator (FZI). This indicator is based on the covariation of porosity and permeability and determines hydraulic flow units (HFU). By definition, an HFU is a volume of a rock body in which the geological and petrophysical properties controlling fluid flow are uniform internally. FZI values are related to porosity, permeability, capillary pressure, lithology distribution, mineralogy, and sedimentary structures and are also influenced by diagenetic processes [46]. The FZI can be calculated as follows [47]:

$$
\mathrm{FZI}=\frac{\mathrm{RQI}}{\mathrm{NPI}}=\frac{0.0314 \sqrt{\frac{\mathrm{k}}{\Phi}}}{\frac{\Phi}{(1-\Phi)}}
$$

where FZI is the flow zone indicator in $\mu \mathrm{m}, \mathrm{NPI}$ is the normalised porosity index, RQI is the reservoir quality index, $\mathrm{k}$ is the permeability in $\mathrm{mD}$ and $\Phi$ is the porosity in a volume fraction.

\section{Results and Discussion}

\subsection{Fracture Network Modelling}

The fracture density of the borehole was determined using two methods, the fractal dimension and the P10 parameter. Both approaches are based on the BHTV data and therefore include all planes detected by BHTV, including faults, veins, joints and bedding planes. The average fracture density in KSF is $4.7 \mathrm{~m}^{-1}$ and in BCF is $2.6 \mathrm{~m}^{-1}$, based on the number of fractures per metre (P10). In the BCF, fracture density is highest near the border of the two formations at $\sim 400 \mathrm{~m}$, below which fracture density decreases significantly $\left(1 \mathrm{~m}^{-1}\right)$, after which fracture density increases steadily with depth (Figure $\left.4 \mathrm{~A}\right)$.

There is no significant difference in the two formations' fractal dimension (D); the average $\mathrm{D}$ value is 1.53. The highest peak in $\mathrm{D}$ values is in the BCF at $500 \mathrm{~m}$ (Figure $4 \mathrm{~B}$ ). The average length exponent $\mathrm{E}$ is -0.80 , varying from -0.24 to -1.48 , and $\mathrm{F}$ is 10.0 .

The orientation of the bedding and fracture planes are slightly different in the two formations. In the sandstone formation, the dip direction of the planes is mainly NE; a smaller group of planes has the dip direction SW. In the claystone, the dip direction of the plains is mainly E, and there are also two groups with different orientations whose dip direction is W and NW (Figure 5). This difference was taken into account during the modelling of the fracture system.

The fracture network was simulated in a $150 \times 150 \times 845 \mathrm{~m}$ cuboid around the borehole. The presence of interconnected subsystems can characterise the simulated fracture networks. Based on ten runs, two typical geometries were distinguished. In the first case, the whole fracture system defines one communicating group (Figure 6A), while in the other case, there are two connected subgroups in the fracture network. The boundary of the two subgroups is located in the BCF at $670 \mathrm{~m}$ (Figure 6B). 

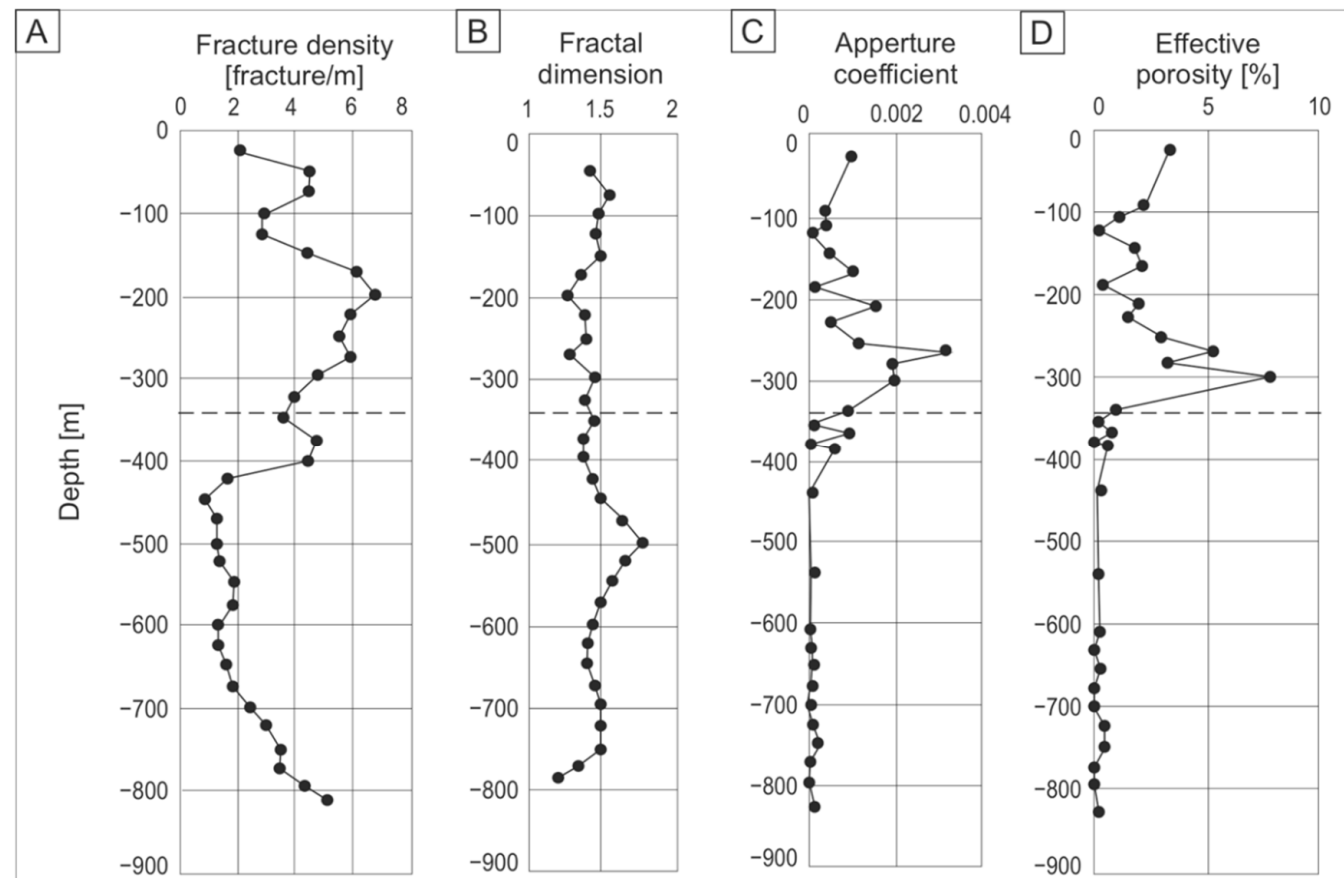

Figure 4. (A) Fracture density log expressed with the number of fractures per metre (P10 parameter); (B) Fractal dimension log of the well, determined at every $50 \mathrm{~m}$, with $25 \mathrm{~m}$ overlap; (C) Aperture coefficient log along the well; (D) Effective porosity log of the well. Dashed lines indicate the border between the KSF and the BCF.
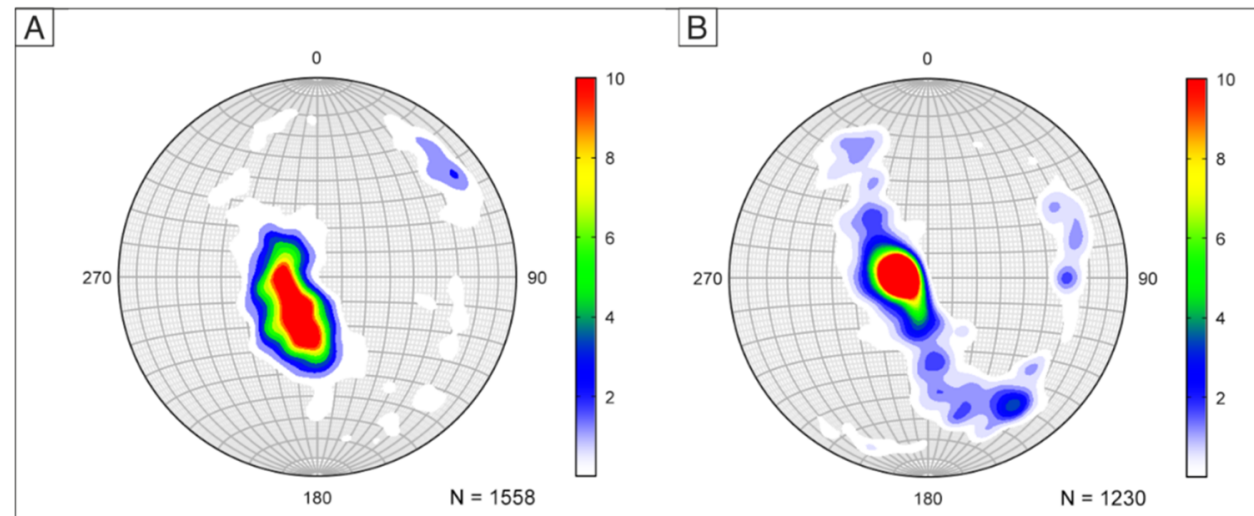

Figure 5. Lower hemisphere stereographic projection of the poles of the bedding and fracture planes of the KSF (A) and the BCF (B) based on BHTV data on Schmidt net. The isolines denote a $2 \%$ increase in frequency. 


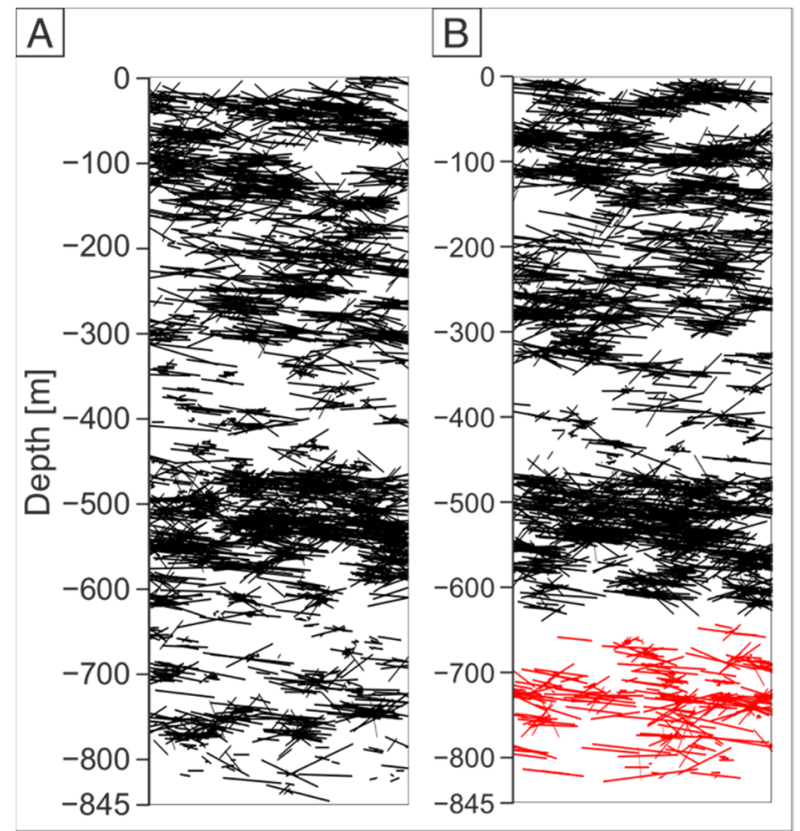

Figure 6. Vertical east-west sections of typical simulated fracture network geometry patterns $(\mathbf{A}, \mathbf{B})$ based on ten individual runs of the BAF-3 well. Different colours indicate the communicating fracture groups within the well. The width of the sections is $150 \mathrm{~m}$.

\subsection{Hydrogeological Evaluation of the Fracture Network}

The fractures' calibrated aperture coefficient (A) values are significantly higher in the sandstone than claystone. In the sandstone body, the A values range from $1 \times 10^{-4}$ to $3 \times 10^{-4}$ (Figure 4C). So, the hydraulic aperture of a fracture in KSF with a diameter of $1 \mathrm{~m}$ can vary from 0.1 to $0.3 \mathrm{~mm}$. In the claystone, the fracture aperture coefficient ranges between $6 \times 10^{-6}$ and $1 \times 10^{-4}$, which means that the hydraulic aperture of a $1 \mathrm{~m}$ fracture in BCF varies between $6 \mu \mathrm{m}$ and $0.1 \mathrm{~mm}$. The effective porosity log follows the anomalies seen in the aperture coefficient log. The upper section of the borehole has high effective porosities compared to the lower half of the well. In the sandstone, the highest porosity value is $7 \%$ at $300 \mathrm{~m}$, while the porosity in the claystone does not reach $1 \%$ (Figure $4 \mathrm{D}$ ).

Based on the poro-perm diagram, two trends describe the hydraulic behaviour of the well (Figure 7A). The permeability data were derived from hydraulic measurements of the borehole, while the porosity data were estimated based on the DFN model and calibrated aperture coefficients. Both trends show an excellent fit $\left(R_{1}=0.996, R_{2}=0.972\right)$. The upper and lower parts of the borehole lie along with two distinct poro-perm trends, indicating the characteristics of the two different formations. The orange trend is predominant in the $\mathrm{BCF}$, while the blue trend is dominant in the KSF.

The FZI values show the same characteristics as the poro-perm diagram (Figure 7B). The sandstone forms a single HFU in the upper part of the borehole based on the FZI values. The transition zone between the two formations exhibits its own HFU. In the lower part of the borehole, the FZI values in the claystone vary considerably. It contains two well-defined zones with higher FZI values (630-700 $\mathrm{m}$ and $775-845 \mathrm{~m}$ ), while the FZI values between these zones are much lower (Figure 7B). 


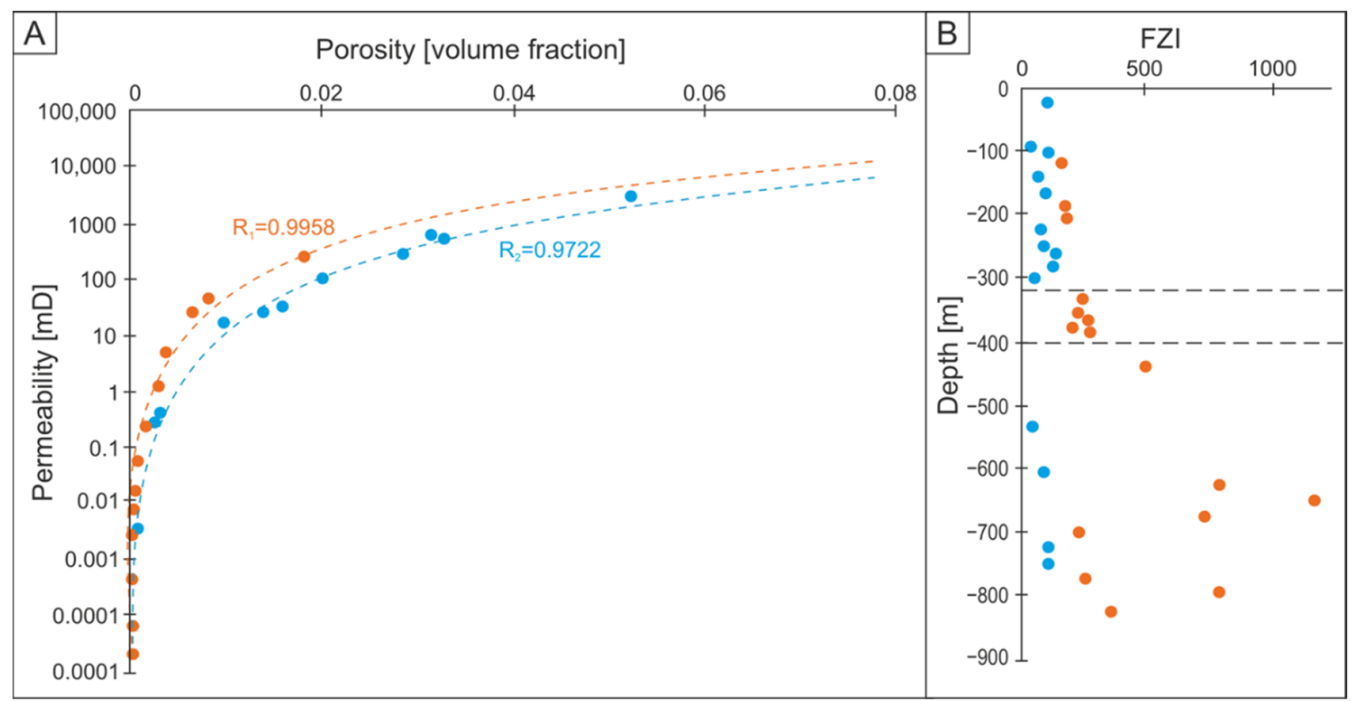

Figure 7. (A) Poro-perm trends of the BAF-3 well based on the measured permeability and computed effective porosity data. (B) The hydraulic flow units of the BAF-3 well are indicated by the flow zone indicator (FZI). Different colours indicate different FZI trends, dashed black lines denote the borders of the HFUs.

\subsection{Interpretation of the Fracture Network Model}

Three zones could be distinguished based on the fracture density and hydrogeological characteristics of the well. The first lies between 0 and $345 \mathrm{~m}$, the second zone between 345 and $400 \mathrm{~m}$ and the third one between 400 and $845 \mathrm{~m}$ (Figure 4). Several factors can influence the fracture density of a rock body; the most important are the rock type, the grain size, the prevailing stress field and the tectonic events. In the BAF-3 well, the main factor affecting the properties of the fracture network is lithology; since the well penetrated two different rock types, sandstone and claystone, and the two formations have identical structural evolution.

The first zone is the upper part of the well between 0 and $345 \mathrm{~m}$, where sandstone is the predominant rock type. The fracture density based on both measured parameters is significantly higher in this zone. The coinciding hydrogeological properties are better (higher transmissivity and effective porosity) than in the other parts of the well. Although this sandstone body is well cemented, it undeniably has some intergranular porosity, and the pores may interact hydrodynamically and so may play a role in the measured transmissivity. Therefore, the fractured porosity calculated using the DFN model and the measured transmissivity data are upper estimates that also take into account the effects of the intergranular porosity of the sandstone. The fracture density data confirm the previous observation that the sandstone more easily and intensively deforms in a brittle way during the same tectonic events than the claystone does, which has self-sealing properties due to its high clay content [33].

From the hydrodynamic perspective, this upper $300 \mathrm{~m}$ interval of the well forms a single HFU more than $300 \mathrm{~m}$ thick; fluid flow controlling properties are internally uniform in this zone. Within this HFU, a single zone at $200 \mathrm{~m}$ has similar FZI values to those computed for the BCF. This behaviour could indicate that the KSF sandstone is becoming finer grained, increasing the clay content in this zone, or could indicate more intensely cemented zones.

Below $343 \mathrm{~m}$, two zones could be distinguished within the BCF based on fracture density and hydrogeological characteristics of the fracture system. The second zone of the well is formed at the boundary between the two formations. This transition zone is located between 343 and $400 \mathrm{~m}$ in the claystone body, where both the fracture density and the hydrogeological properties of the BCF differ from the deeper parts. The fracture density in this zone is the highest in the entire claystone body, associated with higher aperture 
coefficient and effective porosity values. This zone forms a distinct HFU, which means that the rheological and geological properties controlling fluid flow are different from the other parts of the well. The top few dozens of metres of the BCF differ in mineralogical composition from the typical BCF. No authigenic albite is characteristic, and the proportion of K-feldspar also decreases, whereas the typical clay mineral is illite. This different mineralogical composition probably could lead to a significant change in the rheological properties of the rock body and could cause unique fracture geometry features.

The third unit is below the transition zone $(400 \mathrm{~m})$, where the fracture density decreases significantly. The lowest values of fracture density of the whole well were recorded at $450 \mathrm{~m}$. Further down, the fracture density increases continuously, but the aperture coefficient and effective porosity do not change to the same extent. Despite the high fracture density, the hydraulic properties, i.e., transmissivity and porosity values in the claystone, do not increase with depth; transmissivity is lower than $10^{-8} \mathrm{~m}^{2} / \mathrm{s}$, and porosity is in the $10^{-2}-10^{-3}$ range. The aperture coefficients are $3-4$ orders of magnitude smaller than typical for the sandstone body. The various water-rock interaction processes such as dissolution and cementation along the fracture planes could significantly alter the hydrodynamic properties. Small values of the aperture coefficient usually coincide with more closed, highly cemented and self-sealed fractures.

In the lowermost segment of the well, FZI values vary significantly, likely due to tiny changes in porosity or permeability. As a result, distinct and wide HFUs failed to form in the deepest part of the well. In two zones (520-630 and 700-775 m), the FZI values are lower than those typical in the claystone. In these zones, fracture densities (P10 and fractal dimension) also increase compared to their surroundings. This increased fracture number and better hydraulic properties could indicate a coarsening of the average grain size of the formation. Sedimentological descriptions show that fine sandstone interbeds are common in the BCF. In these sections, the number of sandstone layers could be increased compared to the average claystone.

Although fracture density data and hydrodynamic properties change at the boundary between the two lithologies, DFN models along the entire borehole based on ten independent runs show no lithology-related pattern concerning fracture network communication. Despite the distinctly different hydrogeological behaviour of the sandstone and the claystone, the fracture network is connected between the sandstone and the upper segment of claystone in all runs. Nevertheless, the results of some simulations indicate that two fracture subgroups may form along the well, which are not connected. The boundary of these subgroups is located at $670 \mathrm{~m}$ in the studied well. The explanation for this horizon is not clear based on the available information. At about the same depth $(690 \mathrm{~m})$, within the otherwise homogeneous claystone, there is a four-metre-wide reductive layer whose rheological properties could be different. In the reductive zones, the proportions of phyllosilicates are different and the predominant clay mineral in this zone is chlorite instead of illite [16]. However, the influence of the reductive zone on the geometry of the fracture network is unclear. In this zone, the fracture system should be near its percolation threshold; a slight change in modelling parameters can significantly affect the connectivity of the fracture system [43]. Therefore, the connectivity of the fracture network at this depth cannot be predicted with high certainty.

\subsection{Correlation Possibilities with the BAF-2 Well}

Approximately $3.4 \mathrm{~km}$ from the site of this study is the BAF-2 well located, which intersected the BCF for more than 900 metres. For the BAF-2 well, fracture network modelling and evaluation was performed by Tóth et al. [49] using an approach similar to that presented in this study. The main difference between the two wells is that in the BAF-2 well, the caprock of the $\mathrm{BCF}$, the $\mathrm{KSF}$, is missing, and the claystone formation is uncovered (Figure 8). 


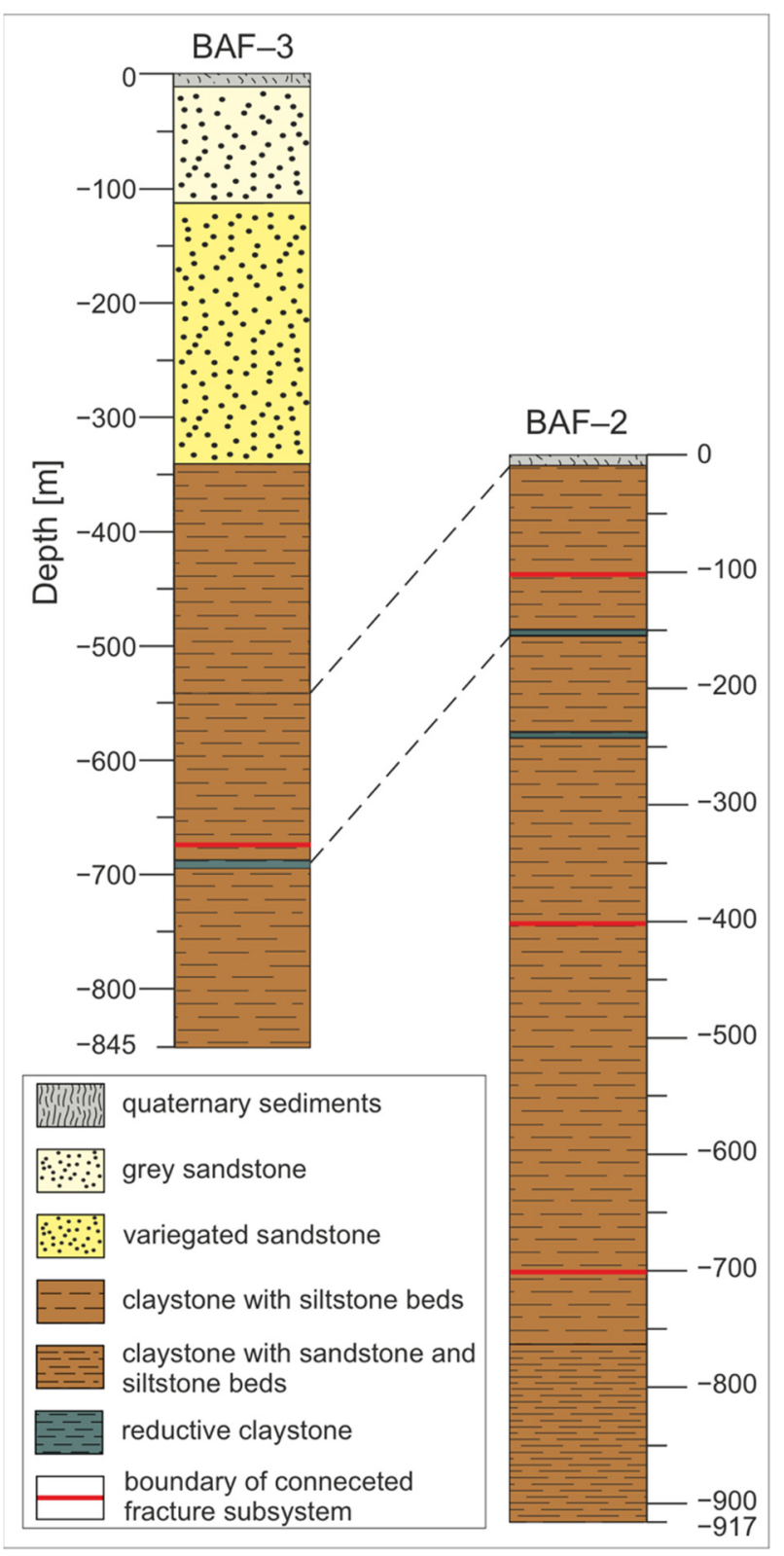

Figure 8. Possible correlation between the BAF-2 and BAF-3 wells based on the lithology and the fracture network modelling.

In the BAF-2 well, a weathered type of the BCF was intersected between 0 and $100 \mathrm{~m}$, resulting from long-term near-surface exposure. Below this interval, the hydrodynamic features indicated by the FZI values are uniform and form a single HFU. Further down, a large-scale tectonic boundary was encountered at $400 \mathrm{~m}$ based on fracture network features and hydrodynamic properties of the well.

Based on sedimentological observations, the uppermost $\sim 200 \mathrm{~m}$ of the BCF has been eroded in the case of the BAF-2, while BAF-3 likely essentially penetrated this segment below the KSF. Good depth markers for the correlation of the two wells are the locations of the reductive zones within the claystone body. In borehole BAF-3, the only reductive zone is at $690 \mathrm{~m}$, corresponding to $347 \mathrm{~m}$ in the claystone. In the BAF-2 well, there are two reductive zones, the recurrence of which in the well is probably due to tectonic activity. These zones appear at approximately 151 and $235 \mathrm{~m}$.

Based on the boundaries of connected fracture subsystems and the location of the reductive layers in the wells, at least $110 \mathrm{~m}$ of claystone is missing from the BAF-2 well. 
Therefore, a few tens of metres short section could be correlated between the uppermost part of the BAF- 2 well and the middle part of the BAF- 3 well, where the reductive layer is located. Just above this horizon the fracture network can be divided into two connected subsystems in both wells what further confirms the possibility for correlation (Figure 8).

On the other hand, the upper $100 \mathrm{~m}$ of the BAF-2 well is highly altered by weathering, which is not the case in the BAF-3 well. Therefore, the characteristics of the fracture system and its hydrogeologic properties differ significantly in the two wells. Due to the different stratigraphic positions and diagenetic processes in the two boreholes, the correlation is not straightforward with borehole $\mathrm{BAF}-2$ regarding the fracture system of the claystone. BAF-3 instead provides essential complementary data to the BAF-2 well model for the uppermost part of the Boda Claystone and its caprock.

\section{Conclusions}

In this study, we investigated the properties of the fracture network and its hydrogeological consequences in a sandstone and a claystone formation in the same well. The hydraulic properties of the fracture system were investigated using measured permeabilities and calculated effective porosities. These were estimated using DFN models for each depth interval for which transmissivity measurements were available.

Based on fracture network properties and hydraulic characteristics, the fracture network could be divided into three zones, the location of which is controlled by the wellbore lithology. The first, more than $300 \mathrm{~m}$ thick zone forms an HFU located in the sandstone. The second zone is about $70 \mathrm{~m}$ thick, along with the transition zone between the two formations, where the predominant rock type is claystone. The fracture density and aperture coefficient are much higher than in the deeper parts of the claystone body. Below this transition zone appears the third zone, where no distinct HFU could form. This means that water-rock interactions have changed the porosity and permeability values to different degrees from point to point.

Based on DFN modelling, the fracture zones of the sandstone and claystone define a geometrically connected fracture system. Deeper parts of the claystone may be divided into two subgroups, but their boundary does not coincide with the lithologic zonation of the borehole. The geometry of the fracture network and the hydraulic properties of the BAF-3 well can provide a basis for further hydrodynamic modelling of the well and its surroundings.

A similar assessment of the fracture system was also performed for borehole BAF-2 previously. Based on the results of the two studies, the correlation between the fracture system of the two wells is uncertain because of the differences in stratigraphic positions and diagenetic processes that altered the BCF in the two wells. This study provides information on the uppermost segment of the BCF and its caprock, which was not penetrated by the BAF-2 well.

Author Contributions: Conceptualization, E.T. and T.M.T.; Investigation, E.T.; Methodology, T.M.T.; Software, T.M.T.; Supervision, T.M.T.; Visualization, E.T.; Writing—original draft, E.T.; Writingreview \& editing, E.H., F.S. and T.M.T. All authors have read and agreed to the published version of the manuscript.

Funding: This study was supported by the ÚNKP-21-3 New National Excellence Program of the Ministry for Innovation and Technology from the National Research, Development and Innovation Fund source, Hungary (grant no. UNKP-21-3-SZTE-464); and by the National Research, Development and Innovation Office, Hungary (grant no. K-138919).

Institutional Review Board Statement: Not applicable.

Informed Consent Statement: Not applicable.

Data Availability Statement: Not applicable. 
Acknowledgments: The Radioactive Waste Management Public Limited Company (RHK Kht.) and the Mecsekérc Zrt. provided access to the BAF-3 well data, we thank Zoltán Máthé and Péter Mucsi for their assistance.

Conflicts of Interest: The authors declare no conflict of interest.

\section{References}

1. Konrád, G.; Hámos, G. Geological Aspects of Determining High Activity Radioactive Waste Depository Sites in Hungary and the Results of the Recent Research. Acta Geogr. Geol. Meteorol. Debrecina 2006, 1, 33-38.

2. Delay, J. Clay Geological Repository Systems: Characterisation and Site Surveying Technologies and Techniques. In Geological Repository Systems for Safe Disposal of Spent Nuclear Fuels and Radioactive Waste; Ahn, J., Ed.; Woodhead Publishing Series in Energy; Woodhead Publ.: Oxford/Cambridge, UK, 2010; ISBN 978-1-84569-542-2.

3. Rao, Z.; Li, G.; Liu, X.; Liu, P.; Li, H.; Liu, S.; Zhu, M.; Guo, C.; Ni, F.; Gong, Z.; et al. Fault Activity in Clay Rock Site Candidate of High Level Radioactive Waste Repository, Tamusu, Inner Mongolia. Minerals 2021, 11, 941. [CrossRef]

4. Anders, M.H.; Laubach, S.E.; Scholz, C.H. Microfractures: A Review. J. Struct. Geol. 2014, 69, 377-394. [CrossRef]

5. Cao, X.; Hu, L.; Wang, J.; Wang, J. Regional Groundwater Flow Assessment in a Prospective High-Level Radioactive Waste Repository of China. Water 2017, 9, 551. [CrossRef]

6. Brace, W.F.; Riley, D.K. Static Uniaxial Deformation of 15 Rocks to 30 Kb. Int. J. Rock Mech. Min. Sci. Geomech. Abstr. 1972, 9, 271-288. [CrossRef]

7. Paterson, M.S. Experimental Rock Deformation-The Brittle Field; Springer: Berlin/Heidelberg, Germany, 1978; ISBN 978-3-540-24023-5.

8. Barabás, A.; Barabás-Stuhl, Á. Geology of the Lower Triassic Jakabhegy Sandstone Formation, Hungary, SE Transdanubia. Acta Geol. Hung. 2005, 48, 1-47. [CrossRef]

9. Konrád, G.; Sebe, K. New Details of Young Tectonic Phenomena in the Western Mecsek Mts and Their Surroundings. Bull. Hung. Geol. Soc. 2010, 140, 135-162.

10. Vadász, E. Magyarország Földtana; Akadémia Kiadó: Budapest, Hungary, 1953.

11. Barabás, A. Geological Conditions of the Permian and Tasks of Surface Geological Investiagations at the Mecsek Ore Deposit. Bull. Hung. Geol. Soc. 1979, 109, 357-365.

12. Magyar, L.; Benei, L.; Halász, A. Re-Evaluation of Archive Pebble Distribution Data for the Upper Permian Bakonya Sandstone Member of the Kővágószőlős Formation, Hungary-A Comparison with the Composition of Cores BAF-1 and BAF-1A. Bull. Hung. Geol. Soc. 2016, 146, 223-232.

13. Barabás, A.; Barabásné Stuhl, Á.; Báldi, T. Magyarország Geológiai Képződményeinek Rétegtana; MOL (Magyar Olaj és Gázipari), MÁFI (Magyar Állami Földtani Intézet): Budapest, Hungary, 1998; ISBN 978-963-671-192-4.

14. Barabás-Stuhl, Á. A Mecsek-Hegységi Felsőpermi Üledékek Tagolása Ciklusos Kifejlődésük Alapján. Bull. Hung. Geol. Soc. 1969, 99, 66-80.

15. Árkai, P.; Demény, A.; Fórizs, I.; Nagy, G.; Balogh, K.; Máthé, Z. Composition, Diagenetic and Post-Diagenetic Alterations of a Possible Radioactive Waste Repository Site: The Boda Albitic Claystone Formation, Southern Hungary. Acta Geol. Hung. 2000, 43, 351-378.

16. Máthé, Z. Results of Mineralogical, Petrological and Geochemical Investigation of Boda Claystone Formation. Ph.D. Thesis, Eötvös Lóránd University, Budapest, Hungary, 2015.

17. Varga, A.; Szakmány, G.; Raucsik, B.; Máthé, Z. Chemical Composition, Provenance and Early Diagenetic Processes of Playa Lake Deposits from the Boda Siltstone Formation (Upper Permian), SW Hungary. Acta Geol. Hung. 2005, 48, 49-68. [CrossRef]

18. Varga, A. Petrology and Geochemistry of the Paleozoic-Lower Triassic Siliciclastic Rocks from Southern Transdanubia, Hungary. Ph.D. Thesis, Eötvös Loránd University, Budapest, Hungary, 2009.

19. Varga, A.; Raucsik, B.; Szakmány, G.; Máthé, Z. Mineralogical, Petrological and Geochemical Characteristics of the Siliciclastic Rock Types of Boda Siltstone Formation. Bull. Hung. Geol. Soc. 2006, 136, 201-231.

20. Konrád, G.; Sebe, K.; Halász, A.; Babinszki, E. Sedimentology of a Permian Playa Lake: The Boda Claystone Formation, Hungary. Geologos 2010, 16, 27-41. [CrossRef]

21. Bernáth, G. (Geo-Log Kft., Budapest, Hungary). A BAF-3 Fúrás Lyukgeofizikai Záródokumentációja (Geophysical Documentation of the BAF-3 Well). 2021, Unpublished report.

22. Benkovics, L.; Mansy, J.-L.; Csontos, L.; Bergerat, F. Folding in the Abaliget Road Cut (Mecsek Mountains). Acta Geol. Hung. 1997, $40,425-440$.

23. Bergerat, F.; Csontos, L. Brittle Tectonics and Paleo-Stress Field in the Mecsek and Villány Mts (Hungary): Correlation with the Opening Mechanism of the Pannonian Basin. Acta Geol. Hung. 1988, 31, 81-100.

24. Csontos, L.; Bergerat, F. Reevaluation of the Neogene Brittle Tectonics of the Mecsek-Villány Are (SW Hungary). Ann. Univ. Sci. Bp. Rolando Eötvös Nomin. Sect. Geol. 1992, 29, 3-12.

25. Fodor, L.; Csontos, L.; Bada, G.; Györfi, I.; Benkovics, L. Tertiary Tectonic Evolution of the Pannonian Basin System and Neighbouring Orogens: A New Synthesis of Palaeostress Data. Geol. Soc. Lond. Spec. Publ. 1999, 156, 295-334. [CrossRef]

26. Sebe, K. Structural Evolution of the Mecsek-Villány Area (SW Hungary) during Post-Rift Phase and Basin Inversion; Croatian Geological Society: Zagreb, Croatia, 2017. 
27. Csontos, L.; Benkovics, L.; Bergerat, F.; Mansy, J.-L.; Wórum, G. Tertiary Deformation History from Seismic Section Study and Fault Analysis in a Former European Tethyan Margin (the Mecsek-Villány Area, SW Hungary). Tectonophysics 2002, 357, 81-102. [CrossRef]

28. Maros, G.; Koroknai, B.; Palotás, K.; Fodor, L.; Dudko, A.; Forián-Szabó, M.; Zilahi-Sebess, L.; Bán-Győri, E. Tectonic Analysis and Structural Evolution of the North-Eastern Mórágy Block. Annu. Rep. Geol. Inst. Hung. 2003, 371-386.

29. Hrabovszki, E.; Tóth, E.; Raucsik, B.; Varga, A.; Schubert, F. A BAF-2 Fúrás Töréses Szerkezeti Elemeinek Mikroszerkezeti És Cementáció Vizsgálata (Bodai Agyagkő Formáció). Földt. Közl. 2017, 147, 245. [CrossRef]

30. Hrabovszki, E.; Tóth, E.; M. Tóth, T.; Máthé, Z.; Schubert, F. Potential Formation Mechanisms of Early Diagenetic Displacive Veins in the Permian Boda Claystone Formation. J. Struct. Geol. 2020, 138, 104098. [CrossRef]

31. Hrabovszki, E.; Tóth, E.; M. Tóth, T.; Garaguly, I.; Futó, I.; Máthé, Z.; Schubert, F. Geochemical and Microtextural Properties of Veins in a Potential High-Level Radioactive Waste Disposal Site. J. Struct. Geol. 2022, 154, 104490. [CrossRef]

32. Tóth, E.; Hrabovszki, E.; M. Tóth, T.; Schubert, F. Shear Strain and Volume Change Associated with Sigmoidal Vein Arrays in the Boda Claystone. J. Struct. Geol. 2020, 138, 104105. [CrossRef]

33. Csicsák, J. (Mecsekérc Zrt, Pécs, Hungary). Hidrológiai, Hidrokémiai Vizsgálati Program (Hydrological, Hydrochemical Study). 1999, Unpublished report.

34. Földváry, K. (Golder Associates, Budapest, Hungary); Mező, G. (Golder Associates, Budapest, Hungary). A BAF-3 Fúrás Hidrogelológiai Vizsgálatai (Hydrogelological Measurements of the BAF-3 Well). 2021, Unpublished report.

35. Barton, C.C.; Larsen, E. Fractal Geometry of Two-Dimensional Fracture Networks at Yucca Mountain, Southwestern Nevada. In Proceedings of the International Symposium on Fundamentals of Rock Joints, Björkliden, Sweden, 15-20 September 1985.

36. La Pointe, P.R. A Method to Characterize Fracture Density and Connectivity through Fractal Geometry. Int. J. Rock Mech. Min. Sci. Geomech. Abstr. 1988, 25, 421-429. [CrossRef]

37. Neuzil, C.E.; Tracy, J.V. Flow through Fractures. Water Resour. Res. 1981, 17, 191-199. [CrossRef]

38. M. Tóth, T.; Szúcs, É.; Schubert, F.; Hollós, C. Conceptual Fracture Network Model of the Crystalline Basement of the Szeghalom Dome (Pannonian Basin, SE Hungary). Acta Geol. Hung. 2004, 47, 19-34. [CrossRef]

39. Tóth, T.M. Determination of Geometric Parameters of Fracture Networks Using 1D Data. J. Struct. Geol. 2010, 32, 878-885. [CrossRef]

40. M. Tóth, T. Fracture Network Characterization Using 1D and 2D Data of the Mórágy Granite Body, Southern Hungary. J. Struct. Geol. 2018, 113, 176-187. [CrossRef]

41. Yielding, G.; Walsh, J.; Watterson, J. The Prediction of Small-Scale Faulting in Reservoirs. First Break 1992, 10, 449-460. [CrossRef]

42. Min, K.-B.; Jing, L.; Stephansson, O. Determining the Equivalent Permeability Tensor for Fractured Rock Masses Using a Stochastic REV Approach: Method and Application to the Field Data from Sellafield, UK. Hydrogeol. J. 2004, 12, 497-510. [CrossRef]

43. M. Tóth, T.; Vass, I. Relationship Between the Geometric Parameters of Rock Fractures, the Size of Percolation Clusters and REV. Math. Geosci. 2011, 43, 75-97. [CrossRef]

44. Bauer, M.; Tóth, T.M. Characterization and DFN Modelling of the Fracture Network in a Mesozoic Karst Reservoir: Gomba Olajfield, Paleogene Basin, Central Hungary. J. Pet. Geol. 2017, 40, 319-334. [CrossRef]

45. Olsson, R.; Barton, N. An Improved Model for Hydromechanical Coupling during Shearing of Rock Joints. Int. J. Rock Mech. Min. Sci. 2001, 38, 317-329. [CrossRef]

46. Cheng, C.; Hale, S.; Milsch, H.; Blum, P. Measuring Hydraulic Fracture Apertures: A Comparison of Methods. Solid Earth 2020, 11, 2411-2423. [CrossRef]

47. Pollard, D.D.; Segall, P. Theoretical Displacements and Stresses near Fractures in Rock: With Application to Faults, Joints, Veins, Dikes and Solution Surfaces. In Fracture Mechanics of Rock; Academic Press: London, UK, 1987; ISBN 978-0-12-066266-1.

48. Gudmundsson, A.; Berg, S.S.; Lyslo, K.B.; Skurtveit, E. Fracture Networks and Fluid Transport in Active Fault Zones. J. Struct. Geol. 2001, 23, 343-353. [CrossRef]

49. Tóth, E.; Hrabovszki, E.; Schubert, F.; M. Tóth, T. Discrete Fracture Network (DFN) Modelling of a High-Level Radioactive Waste Repository Host Rock and the Effects on Its Hydrogeological Behaviour. J. Struct. Geol. 2022, 156, 104556. [CrossRef] 